\title{
Groundwater Chloride Concentrations in Domestic Wells and Proximity to Roadways in Vermont, 2011-2018
}

\section{Introduction}

There is growing evidence that deicing salt, in the form of sodium chloride, is affecting groundwater across New England (Mullaney and others, 2009; Lindsey and Rupert, 2012; Medalie, 2013; Pieper and others, 2018), which is often observed as increased chloride concentrations in groundwater (Torizzo and others, 2016; Robinson and others, 2017). Substantial increases were observed in sodium and chloride across the glacial aquifers of the United States and particularly in New England (Lindsey and Rupert, 2012; Medalie, 2013) during the past 30 to 40 years. The U.S. Geological Survey (USGS), in cooperation with the Vermont Department of Health (VDH), analyzed the concentrations of chloride in groundwater samples collected from 4,319 domestic wells across Vermont between 2011 and 2018 . Ninety wells were sampled twice to analyze temporal trends, and the remaining 4,229 wells were sampled once to evaluate geographical patterns.

There are multiple possible sources that can contribute chloride to groundwater. These include fertilizers commonly used in agriculture, animal waste from animal feeding operations, irrigation practices, evapotranspiration, landfill leachates, septic systems, and road deicing compounds applied to roadways or stored in salt sheds (Granato and others, 2015). Although the determination of the source of chloride to groundwater is outside the scope of this study, Heindel (1982) found an association between road deicing practices in Williston and chloride in groundwater wells located within 100 meters $(\mathrm{m})$ of roadways.

Increases in chloride in groundwater can increase the chloride-to-sulfate $\left(\mathrm{Cl} / \mathrm{SO}_{4}\right)$ mass ratio (Stets and others, 2018), which can raise the potential for water to become more corrosive and to leach lead and copper from plumbing. The $\mathrm{Cl} / \mathrm{SO}_{4}$ ratio and alkalinity, or the ability of water to neutralize acid, play major roles in determining the potential to promote galvanic corrosion (PPGC) - an indicator of water corrosivity (Belitz and others, 2016).

Groundwater in Vermont has been characterized as potentially corrosive based on the PPGC and the Langelier saturation index (Belitz and others, 2016). Although these conditions are due in part to the natural chemistry of groundwater, increasing chloride concentrations are likely contributing to

\section{Highlights}

- Chloride concentrations in groundwater were analyzed from approximately 4,319 (or 4 percent) of private wells in Vermont.

- Approximately 1 percent of groundwater samples had chloride concentrations above the U.S. Environmental Protection Agency's secondary maximum contaminant level (SMCL) of 250 milligrams per liter $(\mathrm{mg} / \mathrm{L})$, with a maximum of $3,262 \mathrm{mg} / \mathrm{L}$.

- More than 50 percent of groundwater samples had chloride concentrations below the laboratory reporting level (RL) of $5 \mathrm{mg} / \mathrm{L}$.

- Groundwater in wells closer to a paved road had substantially higher concentrations of chloride than wells farther away and were also five times more likely to exceed the SMCL.

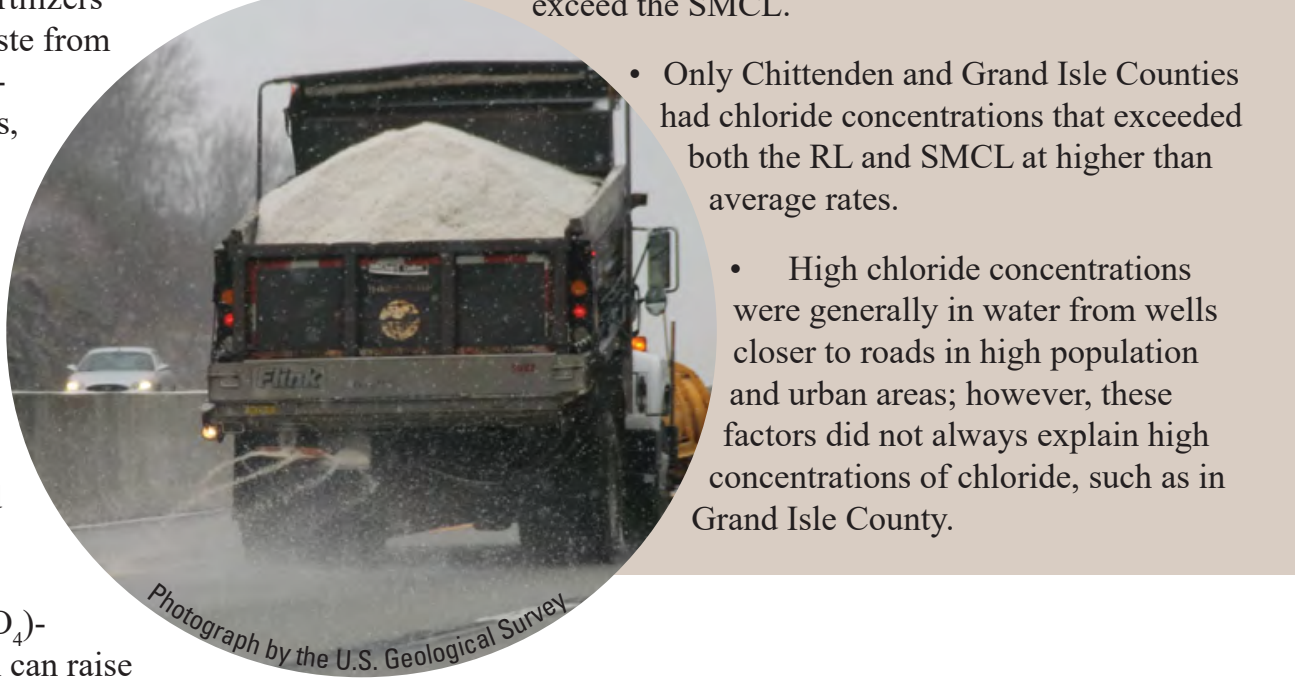

increased corrosivity of New England groundwater. Furthermore, 77 percent of homes in Vermont were built before 1989 (U.S. Census Bureau, 2014) but it was not until 1986 that the Safe Drinking Water Act (SDWA) restricted the maximum allowable lead content in plumbing fixtures to be a weighted average of 8 percent in piping and 0.2 percent in solder and flux (Tiemann, 2017). When coupled with increasing chloride levels, corrosivity has the potential to cause metals, such as lead, to leach from water system components and possibly cause adverse human health effects. 


\section{Methods}

\section{Data Collection}

The VDH compiled chloride concentration data in water from domestic wells and springs between 2011 and 2018 throughout Vermont. These samples were voluntarily provided by the homeowners, analyzed by the VDH Laboratory, reported to well owners, and stored in a drinking water quality database. These results have never been analyzed in aggregate. Of the 5,972 records available, 4,319 were determined to be water samples from untreated drinking water systems and were successfully georeferenced (fig. 1). The data include single chloride concentrations from 4,229 wells to determine the spatial distribution across the State. Ninety wells with two samples eachone taken before the median sample date of September 21, 2015, and one taken after-were used for temporal analysis.

\section{Spatial}

The dataset (Levitt and Larsen, 2019) was checked by the USGS and the VDH for duplicate samples taken at a single site on the same day or at a single site on multiple dates and only sites with single sample dates were used when comparing the spatial variables ( $n=4,229$; fig. 1). For each sample, the VDH computed the distance to the nearest paved road, percent urban and agricultural land use and population density of each well location (VCGI, 2018), and 5-year tract-level household and family data (U.S. Census Bureau, 2018). Location information was then removed from the well data to keep well addresses anonymous.

\section{Quality Control}

Water samples were analyzed for chloride concentrations by the VDH Laboratory, which is certified by the State and the U.S. Environmental Agency (EPA). The laboratory uses EPA method 300.0 for anions in drinking water (Pfaff, 1993) using an ion chromatography system to determine chloride concentrations. The standard sample sequence used by EPA method 300.0 includes analysis of samples for calibration, quality control, ongoing calibration checks, laboratory reagent blanks, fortification (spikes), and laboratory replicates to measure the accuracy and precision of results. Laboratory analysis shows that concentrations in replicate samples for chloride (fig. 2) have a relative percent difference of less than 10 percent.

\section{Analysis of Data}

Because a large part (60 percent) of the chloride concentration data were reported as less than 5 milligrams per liter (mg/L) — the reporting level (RL) in this study — nonparametric statistical methods (rank correlation and rank sum tests) and summary statistics were used to compare concentrations to land use and demographic variables. The Wilcoxon rank sum test (Helsel and Hirsch, 2002) was used to determine whether there was a statistically significant difference in chemical concentrations within and outside the 100-m buffer zone. For this study, a p-value of less than 0.01 was used to indicate a statistically significant difference.

Summary statistics and the percentage of domestic wells with chloride concentrations that exceeded the RL and the secondary maximum contaminant level (SMCL) in Vermont were also compared by county. A total of eight statistics were

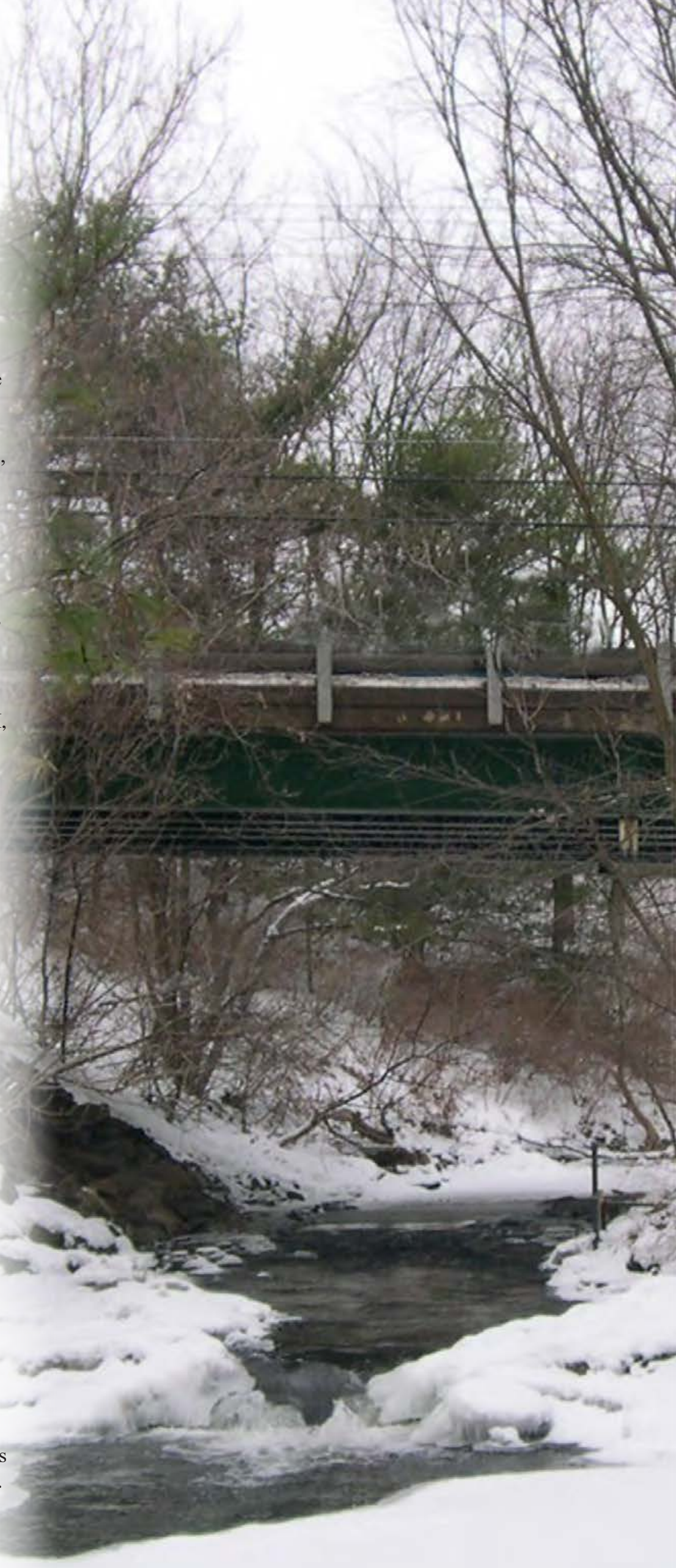

Photograph by the U.S. Geological Survey 


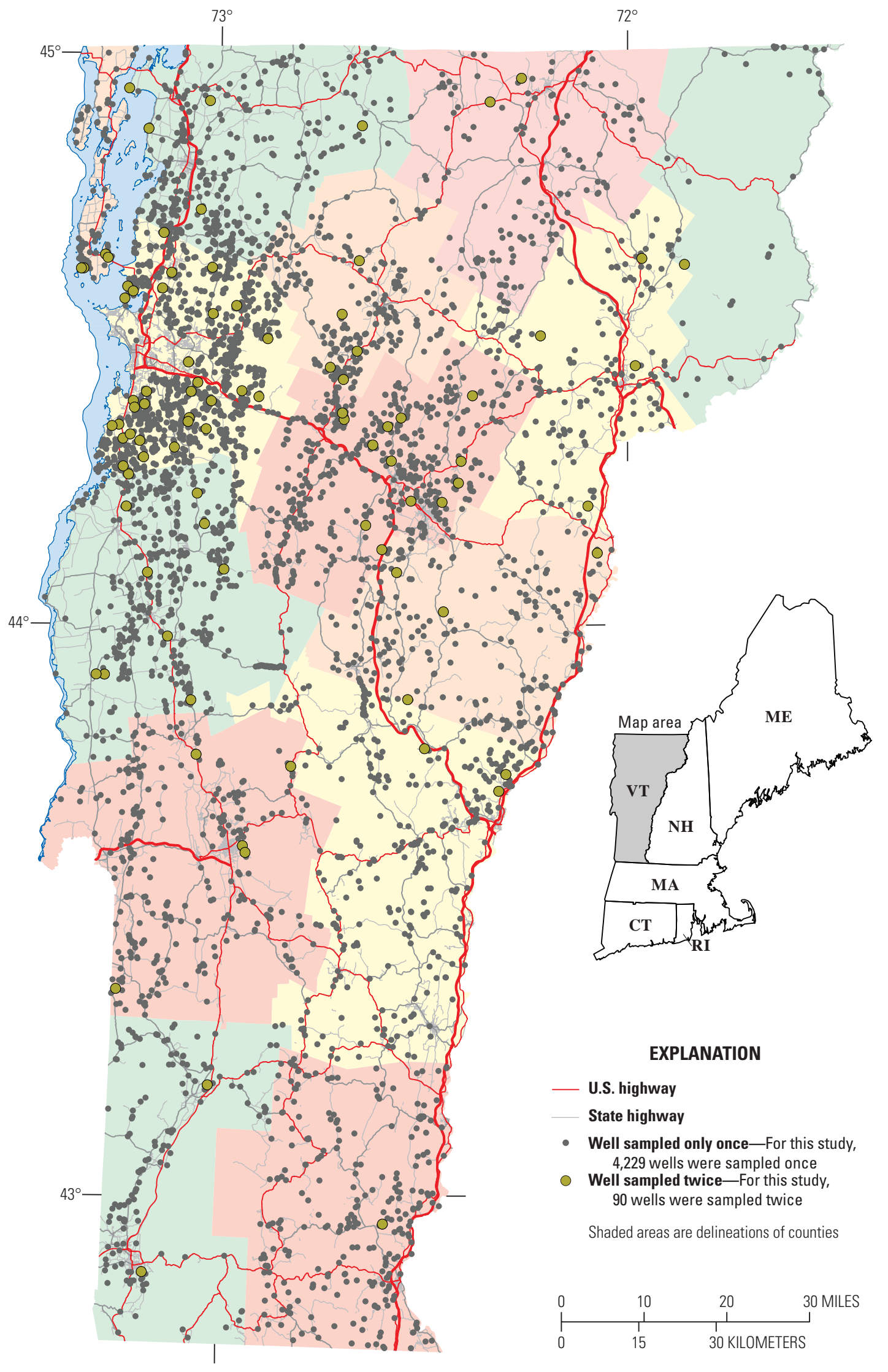

Base from Vermont Department of Health digital data, 2018

Transverse Mercator projection

North American Datum of 1983

State planar feet Vermont FIPS 440

Figure 1. Location of wells sampled for chloride in Vermont from 2011 to 2018. 


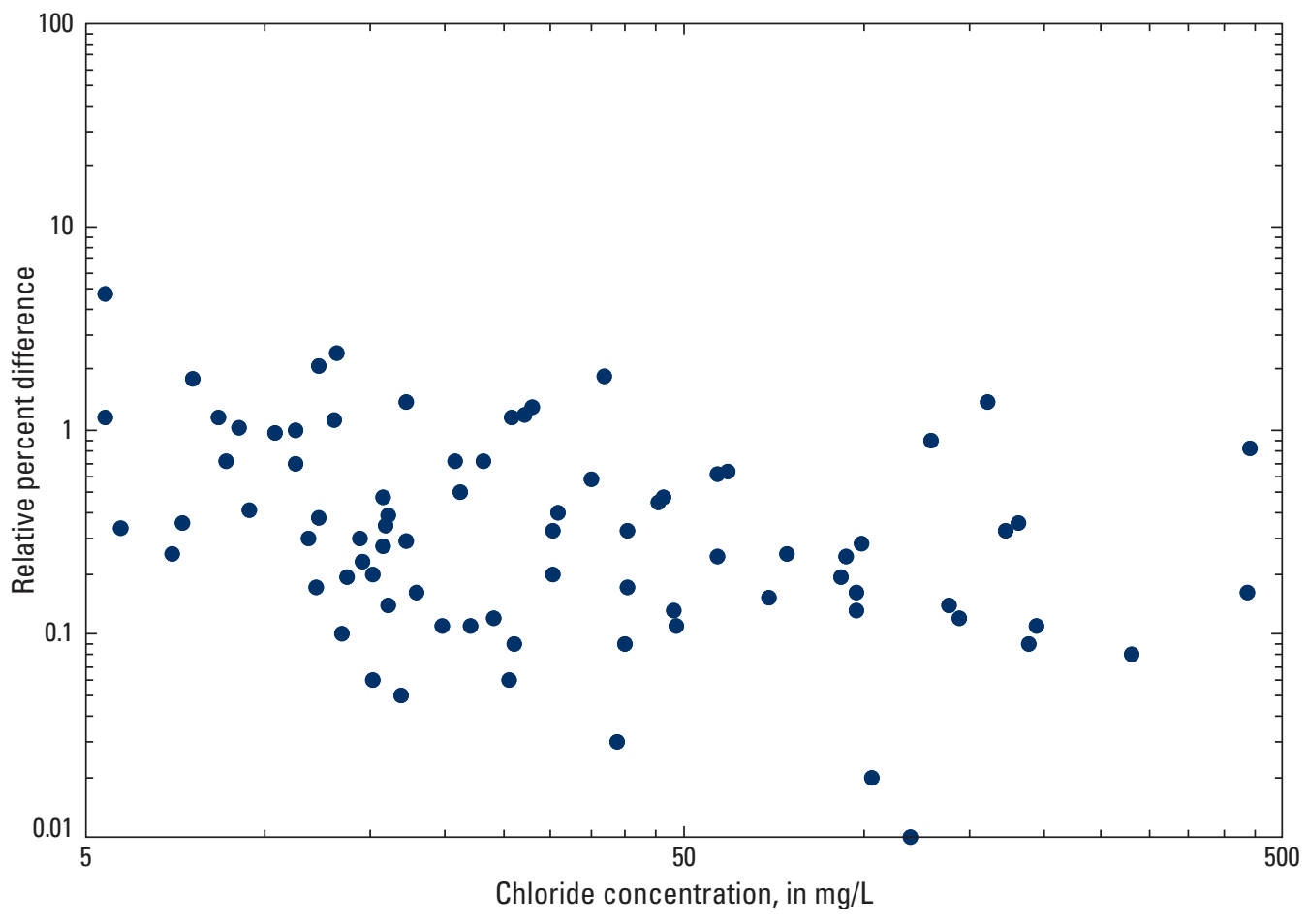

Figure 2. Replicate sample analysis of chloride concentrations for samples collected in Vermont from 2011 to 2018. The reporting level for chloride is 5 milligrams per liter (mg/L).

computed for each county (not including minimum, which was $<5 \mathrm{mg} / \mathrm{L}$ for all counties): median, 75th, 90th, 95th, 99th, maximum (100th) percentiles, percent $>$ RL, and percent $>$ SMCL. To qualitatively compare the counties by overall chloride concentration, counties were divided into groups by chloride level. The chloride level (table 1) was defined as low when zero to two summary statistics were above the statewide value, moderate when three to five were above the statewide value, and high when more than six summary statistics were above the statewide value. This characterization allowed for further analysis of the distribution of chloride concentrations in domestic wells across the State, including how the concentrations may relate to road proximity, land use, and population density.

For this study, an equal-area (65-square-kilometers $\left.\left[\mathrm{km}^{2}\right]\right)$ grid approach (Belitz and others, 2010) was used to characterize maximum chloride concentrations. The resulting map (fig. 3) was overlain with paved roadways to help visualize spatial patterns of chloride concentrations and high-chloride-concentration hotspots. In combination with the summary statistics and correlations related to geography, this method allows for statewide comparison of chloride concentrations and proxies for road proximity, such as population density and urban land cover. It also highlights areas of the State that are unsampled.

On the temporal scale, an increase, decrease, or no change was determined by subtracting the first chloride concentration at each well from the second for the 90 wells sampled before and after the median date of September 15, 2015. A change, no matter the magnitude, was considered an increase or decrease when the calculated difference was nonzero. When concentrations from both sampling dates at any well were censored $(<\mathrm{RL})$, the result was considered "no change." If the concentration at a well changed from below the reporting level $(<\mathrm{RL})$ to above the reporting limit $(>\mathrm{RL})$, this was an increase; if the converse was true, it was a decrease. These three groups (increase, decrease, and no change) were then compared to variables related to well setting and sample timing. 
Table 1. Summary statistics of chloride concentrations by county for 4,229 wells in Vermont from 2011 to 2018.

[Values in shaded cells represent county values greater than or equal to the State value for that column. Chloride level is designated as high, $>6$ shaded cells; moderate, 3 to 5 shaded cells; or low, less than $(<) 3$ shaded cells. Min, minimum; Max, maximum; \%, percent; >, greater than; RL, reporting level; SMCL, secondary maximum contamination level; - - , not applicable]

\begin{tabular}{|c|c|c|c|c|c|c|c|c|c|c|c|}
\hline County & Number of samples & Min & Median & $75 \%$ & $90 \%$ & $95 \%$ & $99 \%$ & Max & $\%>\mathbf{R L}$ & $\%>$ SMCL & Chloride level \\
\hline Addison & 474 & $<5$ & $<5$ & 15 & 51 & 88 & 225 & 705 & 42 & 0.8 & Moderate \\
\hline Bennington & 141 & $<5$ & $<5$ & 12 & 41 & 77 & 118 & 189 & 42 & 0.0 & Low \\
\hline Caledonia & 164 & $<5$ & $<5$ & 6 & 23 & 44 & 117 & 372 & 28 & 0.6 & Low \\
\hline Chittenden & 1,057 & $<5$ & $<5$ & 16 & 53 & 116 & 300 & 3,262 & 45 & 1.6 & High \\
\hline Essex & 34 & $<5$ & $<5$ & $<5$ & 58 & 150 & 250 & 295 & 21 & 2.9 & Moderate \\
\hline Franklin & 361 & $<5$ & $<5$ & 14 & 43 & 70 & 169 & 218 & 47 & 0.0 & Low \\
\hline Grand Isle & 68 & $<5$ & 23 & 65 & 116 & 223 & 614 & 885 & 78 & 4.4 & High \\
\hline Lamoille & 242 & $<5$ & $<5$ & 15 & 41 & 60 & 198 & 270 & 42 & 0.4 & Low \\
\hline Orange & 229 & $<5$ & $<5$ & 8 & 37 & 81 & 189 & 323 & 32 & 0.4 & Low \\
\hline Orleans & 128 & $<5$ & $<5$ & 6 & 16 & 29 & 223 & 291 & 27 & 1.6 & Low \\
\hline Rutland & 276 & $<5$ & $<5$ & 14 & 68 & 108 & 225 & 313 & 39 & 0.4 & Moderate \\
\hline Washington & 497 & $<5$ & $<5$ & 11 & 58 & 97 & 402 & 1,028 & 35 & 1.8 & Moderate \\
\hline Windham & 266 & $<5$ & $<5$ & 16 & 52 & 94 & 311 & 468 & 39 & 1.5 & Moderate \\
\hline Windsor & 292 & $<5$ & $<5$ & 11 & 44 & 116 & 452 & 2,200 & 33 & 1.7 & Moderate \\
\hline Statewide & 4,229 & $<5$ & $<5$ & 13 & 50 & 97 & 269 & 3,262 & 40 & 1.2 & - \\
\hline
\end{tabular}

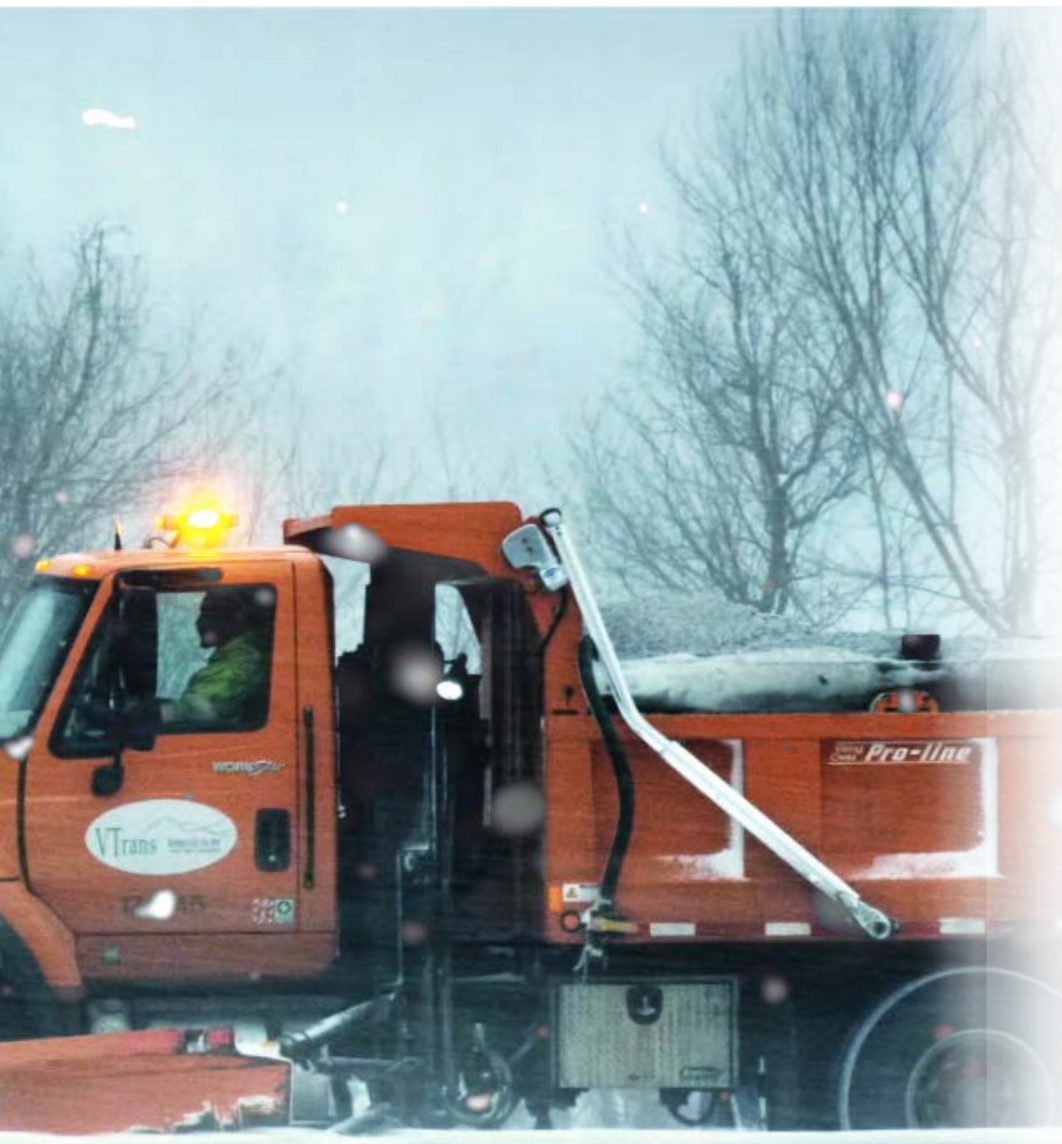

Photograph courtesy of the Vermont Agency of Transportation

\section{Results}

\section{Spatial}

Equal-area grid analysis (fig. 3 ) of the 4,229 wells sampled once shows that high chloride concentrations in wells are widely distributed across the State but are generally closer to roads and urban centers. Unsampled grid cells (shown in white) are areas that could be candidates for future sampling efforts. Wilcoxon rank sum test results showed that wells closer than $100 \mathrm{~m}$ to roads had significantly $(\mathrm{p}<0.001)$ higher concentrations of chloride than those wells more than $100 \mathrm{~m}$ from roads (fig. 4).

Summary statistics and the percent of samples with concentrations of chloride greater than the RL (table 1) illustrate the differences among the counties. Thirteen out of 14 counties have at least one domestic well with a concentration of chloride higher than the EPA SMCL of $250 \mathrm{mg} / \mathrm{L}$ (U.S. Environmental Protection Agency, 2019). Chittenden and Grand Isle Counties had higher concentrations of chloride than statewide concentrations and are the only two counties with a greater percentage of wells with concentrations above both the RL and the SMCL than statewide percentages. Concentrations of chloride in wells in Chittenden County are related to distance to road but in Grand Isle County are not (table 2). In the counties with the strongest chloride correlation to distance-to-road, Washington $($ rho $=-0.47, \mathrm{p}<0.01)$ and Windham $($ rho $=-0.46, \mathrm{p}<0.01)$ had concentration distributions similar to the statewide chloride distribution (table 1).

Spearman rank correlation (Helsel and Hirsch, 2002) results for the entire State showed that wells closer to a paved road in densely populated and urban areas were significantly correlated with higher concentrations of chloride, with the strongest correlation related to proximity to roads ( $\mathrm{rho}=-0.33 ; \mathrm{p}<0.01$ ). The application of road deicing salt and (or) contamination related to high population areas may influence the concentration 


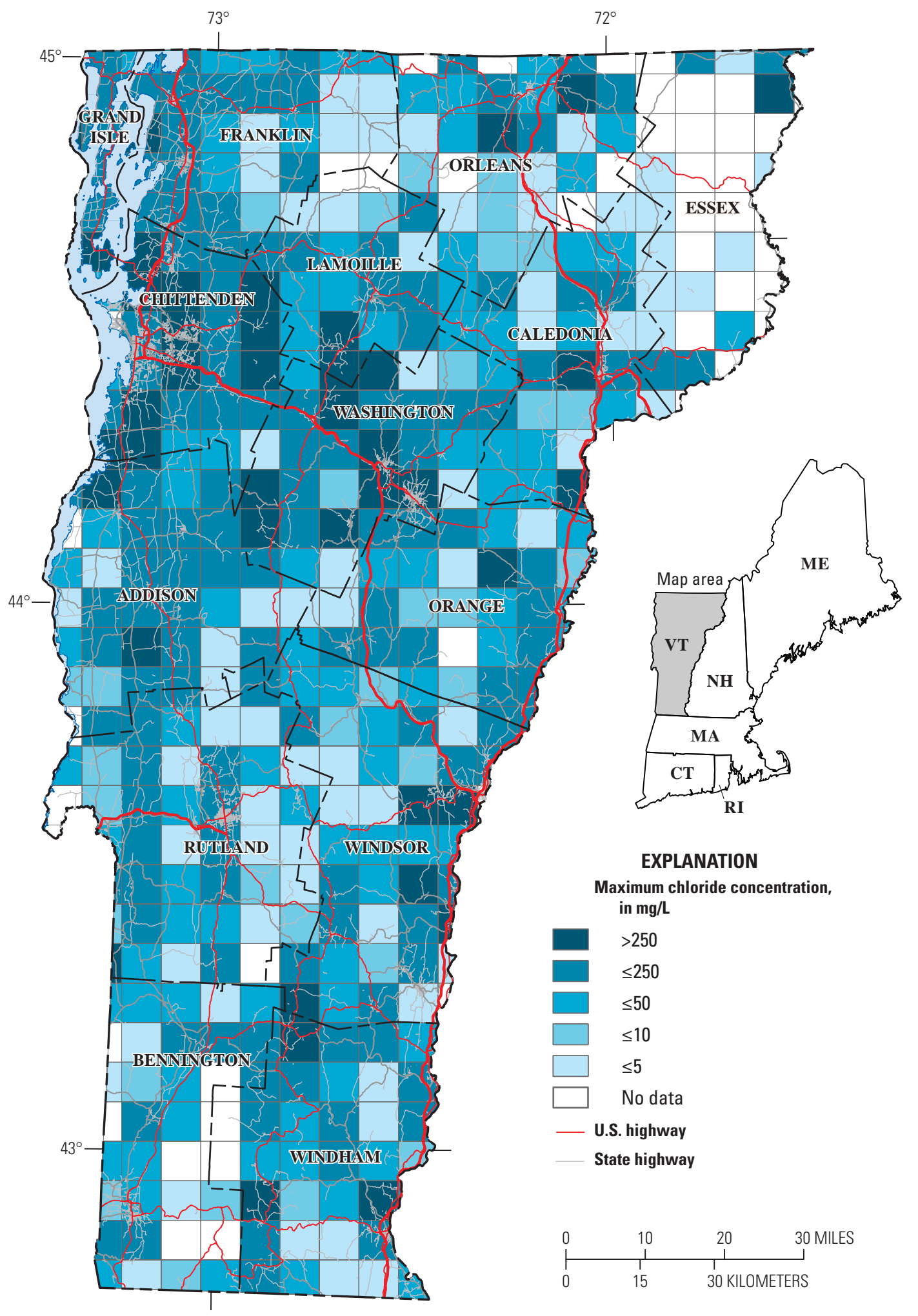

Base from Vermont Department of Health digital data, 2018

Transverse Mercator projection

North American Datum of 1983

State planar feet Vermont FIPS 440

Figure 3. Maximum chloride concentrations in Vermont from 2011 to 2018 by 65-square-kilometer equal-area grid cell. The reporting level for chloride is 5 milligrams per liter $(\mathrm{mg} / \mathrm{L})$. 


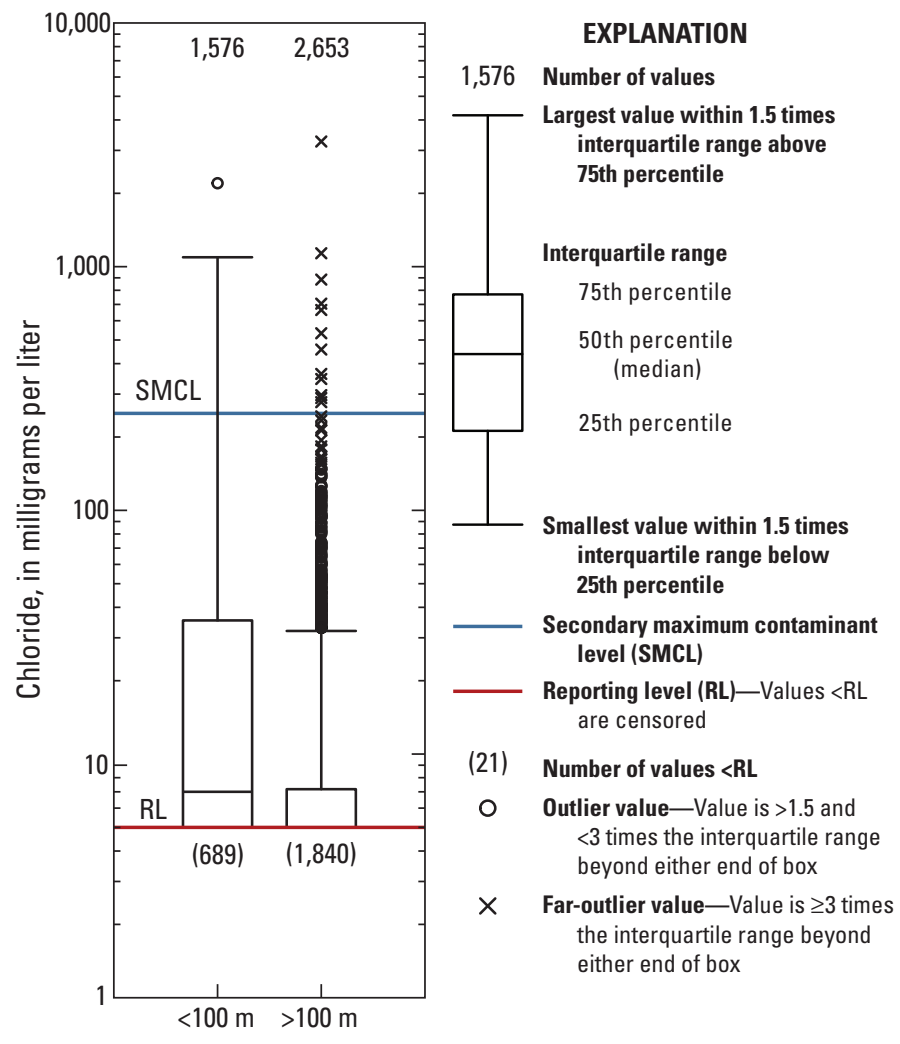

Figure 4. Chloride concentrations from 4,229 domestic wells in Vermont sampled from 2011 to 2018, grouped by proximity (less than $[<]$ or more than [>] 100 meters [m]) to nearest paved road. The U.S. Environmental Protection Agency's secondary maximum contaminant level $(S M C L)$ is 250 milligrams per liter $(\mathrm{mg} / \mathrm{L})$, and the reporting level (RL) is $5 \mathrm{mg} / \mathrm{L}$.

Table 2. Median values of land cover variables and relation to chloride concentrations in Vermont from 2011 to 2018, by county.

[Values are medians by county. Values in red typeface denote that the correlation is significant $(\mathrm{p}<0.01)$ between chloride concentrations and the land use and demographic variable in each county. m, meter]

\begin{tabular}{|c|c|c|c|c|c|c|}
\hline \multirow[b]{2}{*}{ County } & \multirow[b]{2}{*}{$\begin{array}{c}\text { Number } \\
\text { of } \\
\text { samples }\end{array}$} & \multicolumn{4}{|c|}{ Land cover variables } & \multirow[b]{2}{*}{ Interpretation } \\
\hline & & $\begin{array}{c}\text { Median } \\
\text { distance to } \\
\text { nearest road } \\
\text { (m) }\end{array}$ & $\begin{array}{c}\text { Median } \\
\text { population } \\
\text { density (within } \\
500-m \text { radius) }\end{array}$ & $\begin{array}{c}\text { Median } \\
\text { percent urban } \\
\text { land cover } \\
\text { (within } 500-m \\
\text { radius) }\end{array}$ & $\begin{array}{c}\text { Median } \\
\text { percent agri- } \\
\text { cultural land } \\
\text { cover (within } \\
500-m \text { radius) }\end{array}$ & \\
\hline Addison & 474 & 175 & 32 & 6 & 33 & Agricultural, wells close to roads \\
\hline Caledonia & 164 & 604 & 24 & 7 & 12 & Low population density \\
\hline Chittenden & 1,057 & 189 & 52 & 7 & 26 & High population density, wells close to roads \\
\hline Essex & 34 & 362 & 25 & 9 & 3 & Low population density, small sample size \\
\hline Franklin & 361 & 111 & 52 & 10 & 29 & All variables important \\
\hline Grand Isle & 68 & 294 & 49 & 8 & 34 & Agricultural, small sample size \\
\hline Rutland & 276 & 147 & 42 & 8 & 18 & High population density, wells close to roads \\
\hline Washington & 497 & 413 & 39 & 9 & 13 & All variables important \\
\hline Windham & 266 & 172 & 41 & 8 & 8 & All variables important \\
\hline Windsor & 292 & 186 & 30 & 8 & 12 & Wells close to roads \\
\hline Statewide & 4,229 & 220 & 41 & 8 & 19 & All variables important \\
\hline
\end{tabular}


of chloride in domestic wells. Agricultural sources may also contribute chloride to domestic wells, but concentrations were weakly correlated to agricultural land use $(\mathrm{rho}=0.15 ; \mathrm{p}=<0.01)$. This analysis suggests that the proximity of wells to roads and high population density are indicators of elevated chloride concentrations at the State and county scale; however, correlations to land use and demographic variables can vary by county (fig. 5).

County-scale correlations between land use and demographic variables and chloride concentrations made it possible to determine potential sources of chloride (table 2). For most counties, concentrations of chloride correlated with distance-to-road and population density. Five of the 14 counties had correlations with agricultural land cover and only 4 counties had significant correlations with all the variables tested.

Three counties (Essex, Grand Isle, and Orleans), had no significant correlation between chloride concentrations and any of the variables tested. They represent counties with moderate, high, and low chloride levels (table 1), respectively. Essex and Grand Isle Counties had a relatively small sample size. Grand Isle had the highest chloride concentrations in the State (except for its maximum concentration) and also the highest median percent agricultural land cover. However, there was no correlation between agricultural land use and concentrations of chloride. Further investigation of Grand Isle's water quality, geology, and well construction information may yield additional insight. Orleans County had generally low chloride concentrations (roughly 75 percent $<\mathrm{RL}$ ), suggesting that high chloride concentrations in domestic wells are not widespread.

Chittenden County, which accounted for 25 percent of the wells used in this study, was the only county other than Grand Isle to have a high chloride level designation (table 1). Chittenden County also accounted for one third (17 out of 51) of the samples with chloride concentrations exceeding the SMCL and more than 40 percent ( 7 out of 17) of the towns that had median chloride concentrations greater than the statewide median. The percent agricultural land cover was higher and the percent urban land cover was lower at wells in Chittenden County than the statewide percentages.

\section{Temporal}

Several wells were sampled twice and used to analyze potential trends in chloride concentrations. Of the 90 wells sampled twice, 25 wells (28 percent) increased, 20 wells (22 percent) decreased, and 45 wells (50 percent) had no change. Forty-one of the 45 samples (91 percent) that had no change in chloride concentration had concentrations below the RL in both sampling events. The characteristics of the land use and demographic variables can be computed by category of change in chloride concentration and are shown in table 3.

Whereas the distance to the nearest road does not seem to greatly affect whether chloride concentrations increased or decreased, the wells with no change were more than three times farther away from a road. Most of these wells with no change had chloride concentrations below the RL, suggesting that wells far from roads are not often contaminated with chloride. Only 22 percent of wells with no change were within the 100-m buffer zone to a paved road, but more than half the wells with an increase or decrease in concentration were within the 100-m buffer. This finding suggests that there may be a temporal or

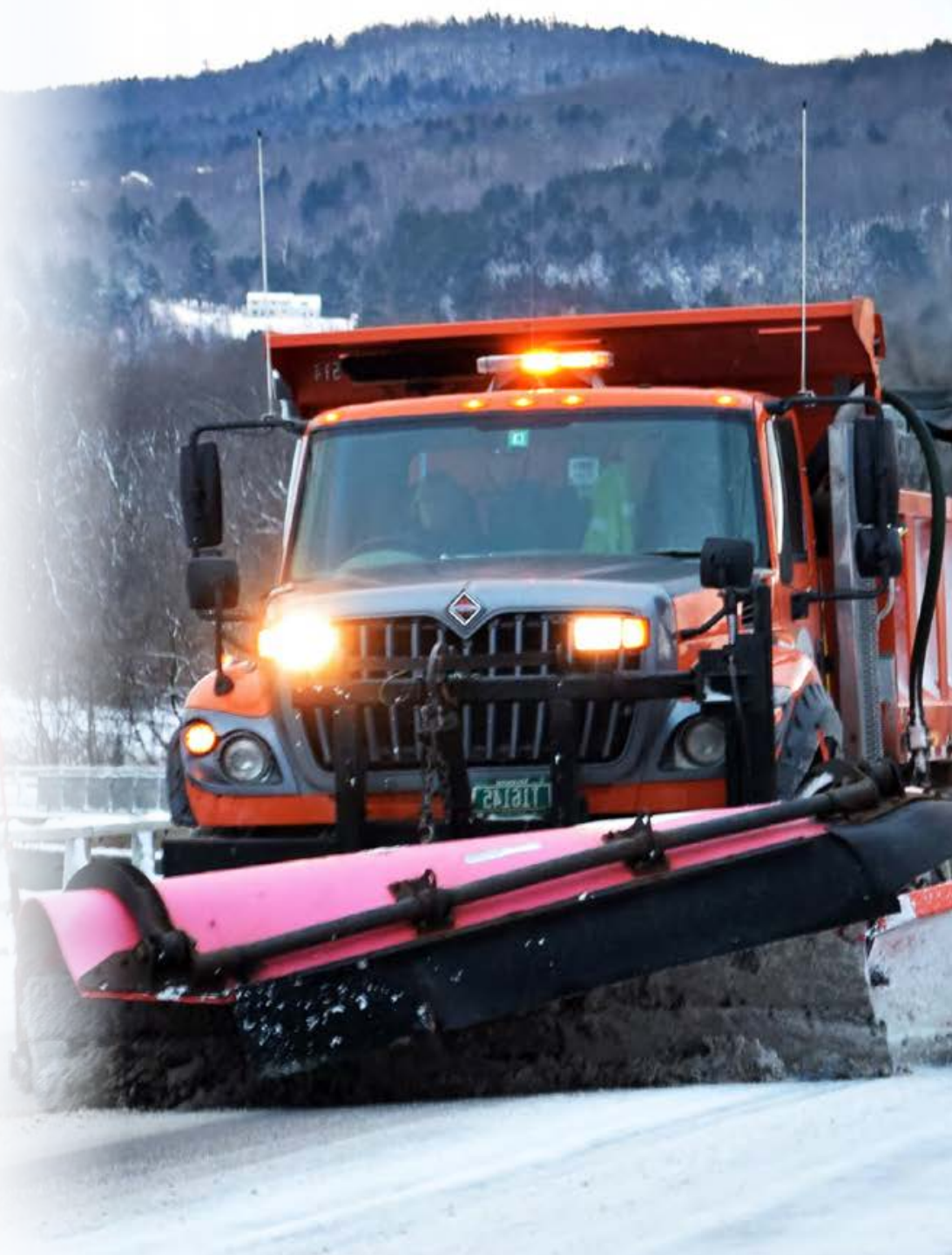




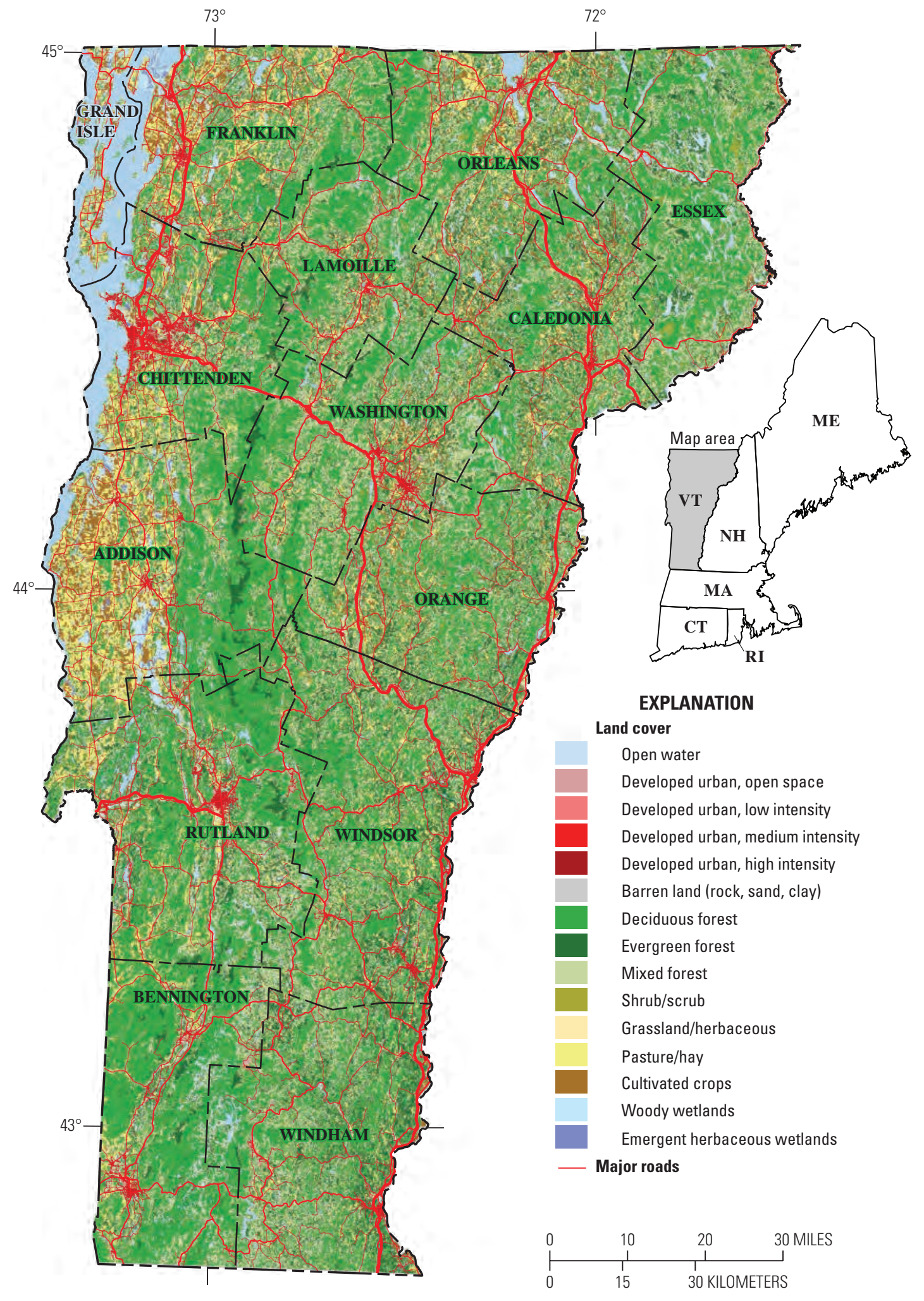

Base from Vermont Department of Health digital data, 2018

Transverse Mercator projections

North American Datum of 1983

State Planar feet Vermont FIPS 440

Figure 5. Land cover in Vermont in 2011. 
Table 3. Characteristics of variables for wells sampled in Vermont from 2011 to 2018 once before and once after September 15, 2015 , by category of change in chloride concentration.

[The September 15, 2015, date is the median sample date for all paired samples. m, meter; \%, percent]

\begin{tabular}{lcccccc}
\hline Category & $\begin{array}{c}\text { Number of } \\
\text { samples }\end{array}$ & $\begin{array}{c}\text { Percent inside } \\
\text { 100-m buffer to } \\
\text { nearest road (\%) }\end{array}$ & $\begin{array}{c}\text { Median distance } \\
\text { to nearest paved } \\
\text { road (m) }\end{array}$ & $\begin{array}{c}\text { Median population } \\
\text { density } \\
\text { (within 500-m } \\
\text { radius) }\end{array}$ & $\begin{array}{c}\text { Median percent } \\
\text { urban land cover } \\
\text { (within 500-m radius) }\end{array}$ & $\begin{array}{c}\text { Median percent agri- } \\
\text { cultural land cover } \\
\text { (within 500-m radius) }\end{array}$ \\
\hline Increase & 25 & 56 & 79 & 62 & 3.4 & 29 \\
Decrease & 20 & 60 & 58 & 47 & 3.1 & 22 \\
No change & 45 & 22 & 300 & 47 & 4.0 & 15 \\
All & 90 & 40 & 201 & 51 & 3.4 & 20 \\
\hline
\end{tabular}

possibly seasonal component to chloride contamination in domestic wells near roadways. Population density also was higher than the overall statewide median for wells that increased in chloride concentration. The percent urban land cover around a well was the same for increases and decreases in chloride, but those wells with no change in chloride concentration had lower percent agricultural land cover than the statewide percentage. Further investigation of these relations may help reveal information about potential seasonality of chloride in domestic wells.

\section{Implications}

As an initial assessment, this report shows that chloride concentrations in domestic wells are related to urban indicators, such as the proximity of the wells to roadways, on a statewide scale (figs. 2 and 3) and that the strength of that relation varies by county (table 2). Chloride concentrations in water from domestic wells in Vermont are most strongly correlated to the proximity of the well to paved roads, urban land use, and population density. This finding may have implications for general drinking water testing recommendations for unregulated drinking water and provides information about possible deicing salt and urban runoff contamination. Determination of whether increasing chloride concentrations are related to increasing corrosivity in domestic wells and whether plumbing is susceptible to leaching of potentially harmful metals into drinking water is an important area of emerging public health concern.

With an estimated 258,535 households in Vermont as of 2017 (U.S. Census Bureau, 2017), approximately 80,000 to 100,000 households (29 to 39 percent) or 180,000 to 240,000 people use privately supplied well water as a main source of drinking water (Johnson and others, 2019; Vermont Department of Health, 2020). Estimates from this study suggest that at least 2,000 to 3,000 people are potentially using groundwater with chloride concentrations that exceed the EPA SMCL of $250 \mathrm{mg} / \mathrm{L}$ in Vermont (table 1). The SMCL for chloride is not human-health based but rather is a nonenforceable aesthetic level set by the EPA. However, of particular importance to human health, and somewhat overlooked, is the contribution of sodium to groundwater from salt application. For individuals on a salt-restricted diet, the EPA guidance level is $20 \mathrm{mg} / \mathrm{L}$ in drinking water (U.S. Environmental Protection Agency, 2003). Therefore, the effects of chloride-related corrosivity and the

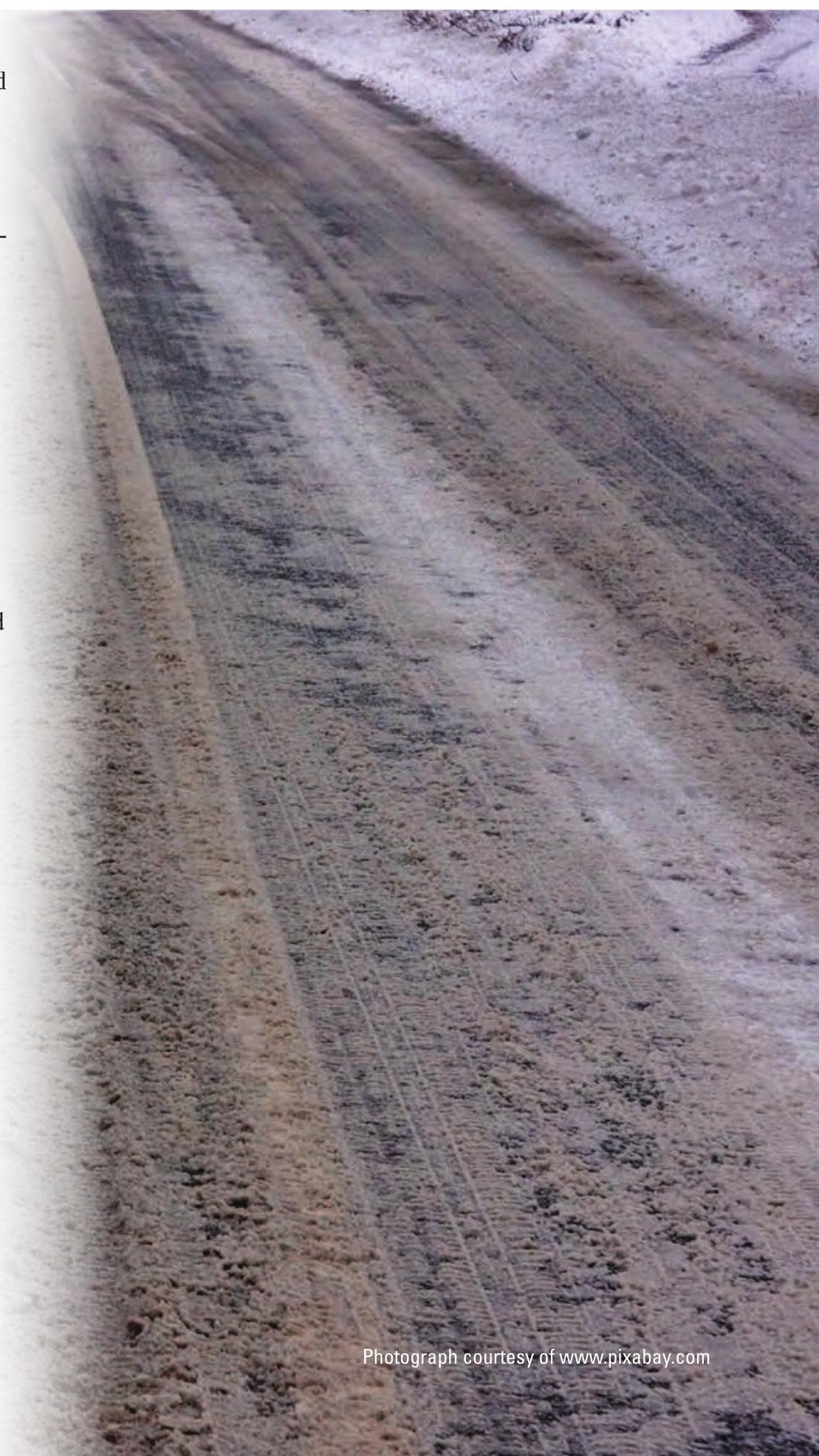


distribution of sodium concentrations in groundwater may warrant additional investigation.

Further analysis of land use and hydrogeology as it affects chloride concentrations in groundwater may be useful to better determine factors related to high chloride concentrations. Sampling near salt storage facilities, which play a major role in chloride contamination (Pieper and others, 2018), could be of use on a local scale. In addition, collecting data in unsampled areas and in counties with small sample sizes may strengthen the correlations between chloride concentrations and land use and demographic variables. Areas of further research might include using chloride to bromide mass ratios and flow studies to determine chloride sources to domestic wells near roadways, especially those with high chloride concentrations. Even though chloride concentrations are higher in domestic wells closer to roads in Vermont than in wells farther away from roads, it remains unclear if these concentrations have been increasing over time because of human effects or whether these elevated concentrations may relate to adverse human health outcomes.

\section{References Cited}

Belitz, K., Jurgens, B.C., and Johnson, T.D., 2016, Potential corrosivity of untreated groundwater in the United States, 2016-5092: U.S. Geological Survey Scientific Investigations Report 2016-5092, 16 p., accessed June 26, 2019, at https://doi.org/10.3133/sir20165092.

Belitz, K., Jurgens, B., Landon, M.K., Fram, M.S., and Johnson, T., 2010, Estimation of aquifer scale proportion using equal area grids-Assessment of regional scale groundwater quality: Water Resources Research, v. 46, no. 11, W11550, 14 p., accessed June 26, 2019, at https://doi.org/10.1029/2010WR009321.

Granato, G.E., DeSimone, L.A., Barbaro, J.R., and Jeznach, L.C., 2015, Methods for evaluating potential sources of chloride in surface waters and groundwaters of the conterminous United States, 2015-1080: U.S. Geological Survey Open-File Report 2015-1080, 89 p., accessed June 26, 2019, at https://doi.org/10.3133/ofr20151080.

Heindel, C., 1982, Road salt effects on ground water in the Williston and St. George area, Vermont: Vermont Geology, v. 2, April, p. 14-19. [Also available at https://dec.vermont.gov/ sites/dec/files/geo/GMG/VTGS_1982.pdf.]

Helsel, D.R., and Hirsch, R.M., 2002, Statistical methods in water resources: U.S. Geological Survey Techniques of WaterResources Investigations, book 4, chap. A3, 522 p., accessed September 6, 2019, at https://doi.org/10.3133/twri04A3.

Johnson, T.D., Belitz, K., and Lombard, M., 2019, Estimating domestic well locations and populations served in the contiguous U.S. for years 2000 and 2010: Science of the Total Environment, v. 687, p. 1261-1273. [Also available at https://doi.org/10.1016/j.scitotenv.2019.06.036.]

Levitt, J.P., and Larsen, S.L., 2019, Chloride concentrations and georeferenced land use variables from domestic wells in Vermont, 2011-2018: U.S. Geological Survey data release, https://doi.org/10.5066/P9MK78K2.
Lindsey, B.D., and Rupert, M.G., 2012, Methods for evaluating temporal groundwater quality data and results of decadal-scale changes in chloride, dissolved solids, and nitrate concentrations in groundwater in the United States, 1988-2010: U.S. Geological Survey Scientific Investigations Report 2012-5049, 46 p., accessed June 26, 2019, at https://doi.org/10.3133/sir20125049.

Medalie, L., 2013, Concentrations of chloride and sodium in groundwater in New Hampshire from 1960 through 2011: U.S. Geological Survey Fact Sheet 2013-3011, 2 p., accessed June 26, 2019, at https://doi.org/10.3133/fs20133011.

Mullaney, J.R., Lorenz, D.L., and Arntson, A.D., 2009, Chloride in groundwater and surface water in areas underlain by the glacial aquifer system, northern United States: U.S. Geological Survey Scientific Investigations Report 2009-5086, 41 p. [Also available at https://doi.org/10.3133/sir20095086.]

Pfaff, J.D., 1993, Method 300.0-Determination of inorganic anions by ion chromatography (rev. 2.1): U.S. Environmental Protection Agency, 28 p., accessed August 19, 2019, at https:/www.epa.gov/sites/production/files/2015-08/ documents/method_300-0_rev_2-1_1993.pdf.

Pieper, K.J., Tang, M., Jones, C.N., Weiss, S., Greene, A., Mohsin, H., Parks, J., and Edwards, M.A., 2018, Impact of road salt on drinking water quality and infrastructure corrosion in private wells: Environmental Science \& Technology, v. 52, no. 24, p. 14078-14087. [Also available at https://doi.org/10.1021/acs.est.8b04709.]

Robinson, H.K., Hasenmueller, E.A., and Chambers, L.G., 2017, Soil as a reservoir for road salt retention leading to its gradual release to groundwater: Applied Geochemistry, v. 83, p. 72-85, accessed May 25, 2019 at https://doi.org/10.1016/ j.apgeochem.2017.01.018.

Stets, E.G., Lee, C.J., Lytle, D.A., and Schock, M.R., 2018, Increasing chloride in rivers of the conterminous U.S. and linkages to potential corrosivity and lead action level exceedances in drinking water: The Science of the Total Environment, v. 613-614, p. 1498-1509. [Also available at https://doi.org/10.1016/j.scitotenv.2017.07.119.]

Tiemann, M., 2017, Safe Drinking Water Act (SDWA)—A summary of the act and its major requirements: Congressional Research Service Report 7-5700, 23 p., accessed August 19, 2019, at https://fas.org/sgp/crs/misc/RL31243.pdf.

Torizzo, A., Dana, A., Garvey, K., and Bruno, M., 2016, Monitoring and tracking chloride trends-An in-stream study examines chloride levels' relation to weather and deicing activities: Stormwater, v. 17, no. 6, p. 18-37, accessed June 25, 2019, at http://digital.stormh20.com/publication/ index.php? $\mathrm{i}=320239 \& \mathrm{~m}=0 \& \mathrm{l}=\& \mathrm{p}=18 \& \mathrm{pre}=\#\{$ percent22page percent22:18, percent22issue_id percent22:320239\}.

U.S. Census Bureau, [2014], Tenure by year structure built; occupied housing units, in 2011-2013 American community survey 3-year estimates: U.S. Census Bureau American FactFinder data, accessed August 19, 2019, at https://factfinder.census.gov/faces/tableservices/ jsf/pages/productview.xhtml?pid=ACS_07_3YR_ B25036\&prodType=table. 
U.S. Census Bureau, 2017, Quick facts-Vermont: U.S. Census Bureau data, accessed December 17, 2018, at https:/www.census.gov/quickfacts/fact/table/VT/PST045218.

U.S. Census Bureau, [2018], Tenure by year structure built; occupied housing units, in 2012-2016 American community survey 5-year estimates: U.S. Census Bureau American FactFinder data, accessed December 17, 2018, at https://factfinder.census.gov/faces/tableservices/jsf/pages/productview.xhtml?pid=ACS_16_5YR_ B25036\&prodType=table.

U.S. Environmental Protection Agency, 2003, Drinking water advisory-Consumer acceptability advice and health effects analysis on sodium: U.S. Environmental Protection Agency 822-R-03-006, 29 p., accessed December 3, 2019, at https://www.epa.gov/sites/production/files/2014-09/documents/support_cc1_sodium_dwreport.pdf.
U.S. Environmental Protection Agency, 2019, Secondary drinking water standards-Guidance for nuisance chemicals: U.S. Environmental Protection Agency web page, accessed December 3, 2019, at https://www.epa.gov/sdwa/secondary-drinkingwater-standards-guidance-nuisance-chemicals.

Vermont Center for Geographic Information (VCGI), 2018, Vermont open geodata portal: Vermont Center for Geographic Information data, accessed December 17, 2018, at https://geodata.vermont.gov/.

Vermont Department of Health, 2020, Environmental public health tracking: Vermont Department of Health data, accessed March 16, 2020, at https://apps.health.vermont.gov/ias/ querytool? Topic $=$ EPHT.

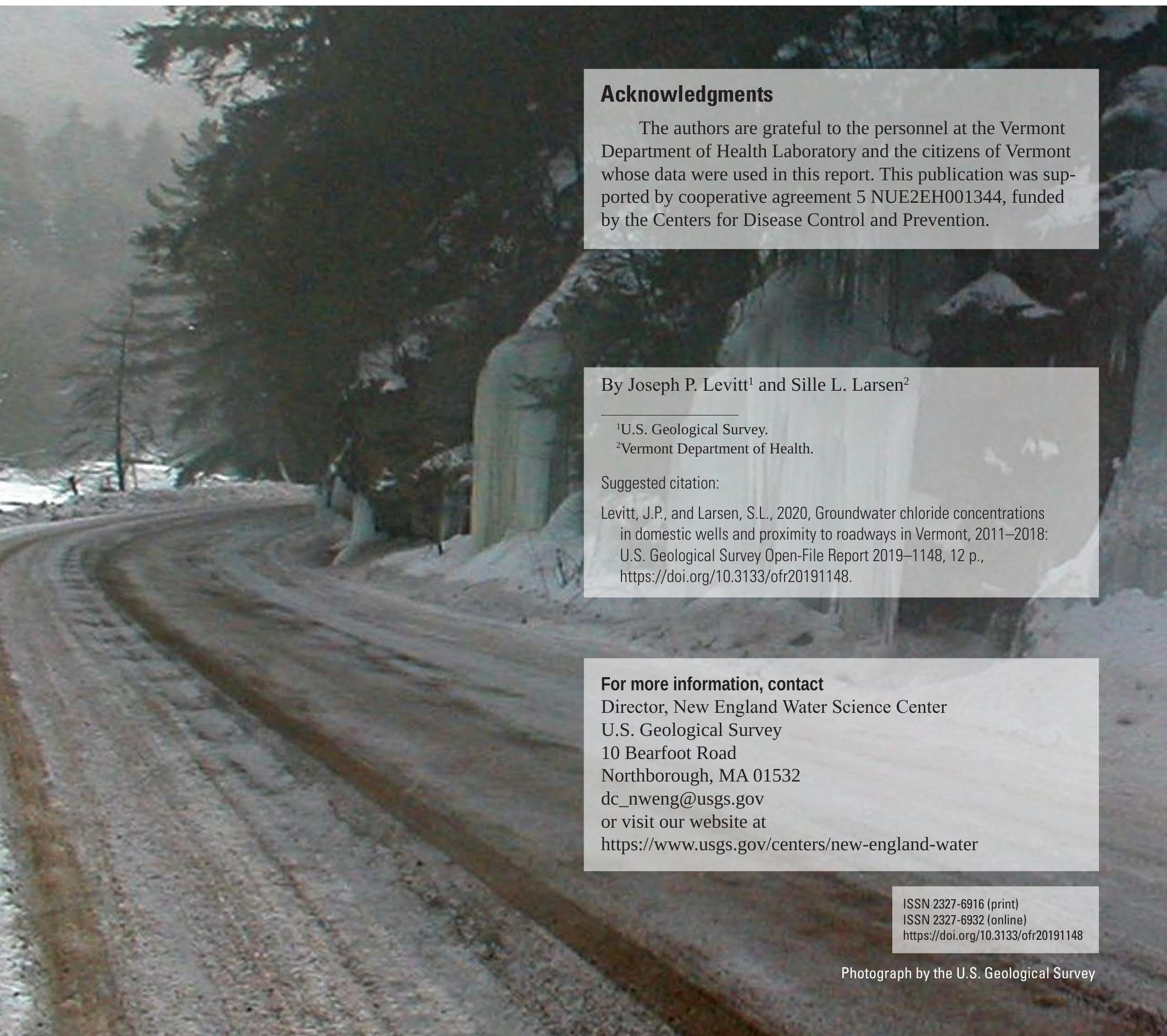

